\title{
COMPARATIVE STUDY ON CONVENTIONAL BLOOD CULTURE AND AUTOMATED BLOOD CULTURE (BACTEC 9050) IN THE EARLY DETECTION OF BACTERIAL ISOLATES IN TERTIARY CARE HOSPITAL OF KUMAUN REGION
}

\author{
Nishat Anjum¹, Umesh², Vinita Rawat', Mukesh Kumar', Mohan S. Deopa ${ }^{5}$
}

1 Junior Resident, Department of Microbiology, Government Medical College, Haldwani, Uttarakhand, India. 2Professor and HOD, Department of Microbiology, Government Medical College, Haldwani, Uttarakhand, India. ${ }_{3}^{3}$ Associate Professor, Department of Microbiology, Government Medical College, Haldwani, Uttarakhand, India. ${ }_{4}^{4}$ Assistant Professor, Department of Microbiology, Government Medical College, Haldwani, Uttarakhand, India. ${ }_{5}^{5}$ Assistant Professor, Department of Microbiology, Government Medical College, Haldwani, Uttarakhand, India.

\section{ABSTRACT}

\section{BACKGROUND}

Blood stream infections range from self-limiting infections to life threatening sepsis that require rapid and aggressive antimicrobial treatment. Timely detection and identification of blood-borne pathogens would be a useful guide for clinicians in initiating the empiric antibiotic therapy.

Objectives-To evaluate the capability, efficiency and reliability of automated blood culture methods (BACTEC 9050) in comparison to conventional blood culture for detection of bacterial isolates in clinically suspected cases of septicaemia.

\section{METHODS}

All the blood culture samples (in duplicate), from 2 different sites, at 2 different times, 30 minutes apart, were taken from suspected cases of septicaemia consecutively during study period (September 2016 to June 2017). Samples were subjected to conventional blood culture and BACTEC 9050 culture system.

\section{RESULTS}

Out of 254 suspected cases of septicaemia, 93 (36.6\%) cases were culture positive. Among these, $60 \%$ were positive with both methods while $36.5 \%$ were positive on BACTEC culture only. Out of 93 positive cases, a total of 100 isolates comprising of grampositive bacteria (62\%), gram-negative bacteria (36\%) and Candida sp. (2\%) were detected. BACTEC 9050 detected all positive samples in within 24 hours while Conventional method detected none within 24 hrs, $25.4 \%$ within 48 hours, and $84.7 \%$ within 86 hours. Among gram-positive bacteria, predominant isolates were Coagulase Negative Staphylococcus (41\%) followed by Enterococcus (9\%). Among gram-negative isolates, 14\% were Pseudomonas sp. followed by $10 \%$ Acinetobacter sp. BACTEC 9050 was observed to be more sensitive (94.9\%) in comparison to conventional blood culture. Mean time of detection was significantly less (11.3 hours) with the BACTEC 9050 than with conventional method (61.7 hours).

\section{CONCLUSIONS}

BACTEC 9050 proved to be a reliable, fast technique with high sensitivity and specificity in identification of the blood stream pathogens in blood culture in comparison to conventional culture methods.

HOW TO CITE THIS ARTICLE: Anjum N, Umesh, Rawat V, et al. Comparative study on conventional blood culture and automated blood culture (BACTEC 9050) in the early detection of bacterial isolates in tertiary care hospital of Kumaun region. J. Evolution Med. Dent. Sci. 2019;8(20):1647-1650, DOI: 10.14260/jemds/2019/364

\section{BACKGROUND}

Blood stream infections range from self-limiting infections to life threatening sepsis that require rapid and aggressive antimicrobial treatment.[1] A wide spectrum of organisms has been described that cause blood stream infections and this spectrum is subject to geographical alteration.[2-5]

Increasing antimicrobial resistance is a worldwide concern. The prevalence of resistance of blood-borne isolates is increasing and it also varies in accordance with geographical and regional location.

'Financial or Other Competing Interest': None.

Submission 01-04-2019, Peer Review 05-05-2019,

Acceptance 11-05-2019, Published 20-05-2019.

Corresponding Author:

Dr. Umesh,

Professor and HOD,

Department of Microbiology,

Government Medical College,

Haldwani, (Nainital),

Uttarakhand, India.

E-mail:drumesh7@rediffmail.com

DOI: $10.14260 /$ jemds $/ 2019 / 364$

\section{(c) (1) $(9)$}

The infection caused by MDR organisms is more likely to prolong the hospital stay, increase the risk of death, and require treatment with more expensive antibiotics. Keeping in mind the high mortality and morbidity associated with septicaemia, right choice of empiric therapy is of importance.[6] In almost all cases, antimicrobial therapy is initiated empirically before the results of blood culture are available.

Rapid detection of bacteria in blood has both therapeutic and prognostic significance. Though newer techniques like nucleic acid probes, polymerase chain reaction and other molecular techniques are available; blood culture still remains the most practical and reliable method in the diagnosis of bloodstream infections. $[7,8]$ Blood cultures provide the best yield for microbiological diagnosis, with sensitivity ranging from $53 \%$ to $90 \% .^{[9]}$

Conventional blood culture methods use culture media like brain heart infusion broth, tryptic soy broth, bile broth, glucose broth etc. But use of conventional methods is limited by less isolation rate, slow growth and inhibition of bacterial growth by antibiotics in patient's blood. 
Instrumentation of blood culture has accomplished rapidness, accuracy and cost effectiveness. Automated blood culture systems like BACTEC, BacT/Alert and Versa trek have been used widely with added advantages like higher isolation rate, faster detection, lesser contamination etc. Several studies done earlier have evaluated the advantages of automated culture over the conventional methods, not only for blood culture, but also for body fluids. The BACTEC 9000 series of blood culture systems are fluorogenic, automated, non-invasive blood culture system designed for processing three to five blood cultures per day.[10]

Therefore, this study was undertaken in a Government Medical College, Haldwani, a tertiary care centre in Kumaun region (Uttarakhand) to evaluate the capability, efficiency and reliability of automated blood culture methods (BACTEC 9050) in comparison to conventional blood culture for detection of bacterial isolates in clinically suspected cases of septicaemia.

\section{Aim of the Study}

To evaluate the efficacy of automated blood culture method (BACTEC 9050) in comparison to conventional blood culture with regards to rate and time of detection of bacterial isolates in clinically suspected cases of septicaemia.

\section{METHODS}

The present cross-sectional study for diagnostic evaluation on conventional blood culture and automated blood culture system (BACTEC 9050) was carried out during the period from September 2016 to June 2017 at Government Medical College, Haldwani, a tertiary care centre in Kumaun region (Uttarakhand).

\section{Procedure}

All the suspected cases of septicaemia were enrolled consecutively during study period and blood culture samples (in duplicate) from 2 different sites at 2 different times (30 minutes apart) were taken. Samples were subjected to conventional blood culture and BACTEC 9050 culture system.

\section{Sample Collection and Processing}

- $10 \mathrm{ml}$ blood was collected aseptically from adult patients and was divided equally into BACTEC blood culture vial (Aerobic) and conventional blood culture bottle containing $50 \mathrm{ml}$ of brain heart infusion broth (Dilution 1:10).[11]

- For paediatric patients, $2 \mathrm{ml}$ of blood was collected and equally transferred into the BACTEC ${ }^{\mathrm{TM}}$ PEDS PLUS/F vial and Conventional blood culture bottle containing $10 \mathrm{ml}$ of brain heart infusion broth.[12]

- The inoculated BACTEC vials and conventional blood culture bottles were transported to the laboratory immediately and incubated for a minimum of 7 days before labelling as negative as per the manufacturer's protocol.[10]

- The bacterial colonies grown on Blood/Chocolate agar and MacConkey agar were processed manually for identification and antimicrobial susceptibility as per standard methods.[13]

\begin{tabular}{|c|c|c|c|}
\hline Parameters & \multicolumn{3}{|c|}{ Total Culture Positive Cases (93) } \\
\hline Gender & & & \\
\hline Male & \multicolumn{3}{|c|}{$50(53.7 \%)$} \\
\hline Female & \multicolumn{3}{|c|}{$43(46.2 \%)$} \\
\hline $\begin{array}{c}\text { Age } \\
\text { (in years) }\end{array}$ & $\begin{array}{c}\text { Male } \\
\text { N (\%) }\end{array}$ & $\begin{array}{c}\text { Female } \\
\text { N (\%) }\end{array}$ & $\begin{array}{r}\text { Total } \\
\text { N (\%) } \\
\end{array}$ \\
\hline$<10$ & $18(36 \%)$ & $09(20.9 \%)$ & $27(29.0 \%)$ \\
\hline $11-20$ & $14(28 \%)$ & $15(34.8 \%)$ & $29(31.1 \%)$ \\
\hline $21-30$ & $04(08 \%)$ & $07(16.2 \%)$ & $11(11.8 \%)$ \\
\hline $31-40$ & $03(06 \%)$ & $03(06.9 \%)$ & $06(06.4 \%)$ \\
\hline $41-50$ & $02(04 \%)$ & $01(02.3 \%)$ & $03(03.2 \%)$ \\
\hline$>50$ & $09(18 \%)$ & $08(18.6 \%)$ & $17(18.2 \%)$ \\
\hline Total & $50(53.7 \%)$ & $43(46.2 \%)$ & 93 \\
\hline \multicolumn{4}{|c|}{ Residential Area } \\
\hline \multicolumn{2}{|c|}{ Urban } & \multicolumn{2}{|c|}{$41(44 \%)$} \\
\hline \multicolumn{2}{|c|}{ Rural } & \multicolumn{2}{|c|}{$52(56 \%)$} \\
\hline \multicolumn{2}{|c|}{ Total } & \multicolumn{2}{|c|}{93} \\
\hline \multicolumn{4}{|c|}{$\begin{array}{c}\text { Table 1. Distribution of Culture Positive Cases According to } \\
\text { Gender, Age and Residence }\end{array}$} \\
\hline
\end{tabular}

\section{RESULTS}

Out of 254 suspected cases of septicaemia, 93(36.6\%) cases were culture positive. In present study, males constituted majority $(53.7 \%)$ of the patients with blood stream infections. Maximum patients were from rural area (56\%) and found in 11-20 years (31.1\%), followed by the younger age group of less than 10 years (29\%). (Table 01)

Overall, $35.4 \%$ and $23.2 \%$ of the samples showed positive growths by the automated (BACTEC 9050) and conventional methods respectively. (Table 02)

\begin{tabular}{|c|c|c|c|c|c|}
\hline $\begin{array}{c}\text { Total } \\
\text { Posi- } \\
\text { tive }\end{array}$ & $\begin{array}{c}\text { Culture } \\
\text { Positive } \\
\text { with Both } \\
\text { the } \\
\text { Cases } \\
\text { (N) }\end{array}$ & $\begin{array}{c}\text { Culture } \\
\text { Positive } \\
\text { with } \\
\text { n (\%) }\end{array}$ & $\begin{array}{c}\text { Total } \\
\text { Culture } \\
\text { Positive } \\
\text { only } \\
\text { nith }(\%)\end{array}$ & $\begin{array}{c}\text { Culture } \\
\text { Positive } \\
\text { with Con- } \\
\text { ventional } \\
\text { n (\%) }\end{array}$ & $\begin{array}{c}\text { Total Culture } \\
\text { only } \\
\text { nositive with } \\
\text { Con } \\
\text { ventional } \\
\text { Method } \\
\text { n (\%) }\end{array}$ \\
\hline 93 & $56(60.3 \%)$ & $34(36.5 \%)$ & $\begin{array}{c}90 / 254 \\
(35.4 \%)\end{array}$ & $03(03.2 \%)$ & $\begin{array}{c}59 / 254 \\
(23.2 \%)\end{array}$ \\
\hline \multicolumn{6}{|c|}{ Table 2. Rate of Positivity in Automated (BACTEC 9050) \& } \\
Conventional Culture Methods
\end{tabular}

Out of 93 positive cases, a total of 100 isolates were detected. (Table 03)

\begin{tabular}{|c|c|c|c|}
\hline $\begin{array}{c}\text { Total } \\
\text { Positive } \\
\text { Cases (N) }\end{array}$ & $\begin{array}{c}\text { Single Isolate } \\
\text { Irrespective of } \\
\text { Methods Used } \\
\text { n (\%) }\end{array}$ & $\begin{array}{c}\text { Two Isolates } \\
\text { Irrespective of } \\
\text { Methods Used } \\
\text { n (\%) }\end{array}$ & $\begin{array}{c}\text { Total Number of } \\
\text { Isolates } \\
\text { Irrespective of } \\
\text { Methods Used }\end{array}$ \\
\hline 93 & $92(98.9 \%)$ & $04(04.3 \%)$ & 100 \\
\hline \multicolumn{2}{|c|}{ Table 3. Detection of Bacterial Isolates in Automated (BACTEC } \\
9050) \& Conventional Culture Methods
\end{tabular}

Among all the isolates, $62(62 \%)$ isolates were grampositive while $36(36 \%)$ isolates were found to be gramnegative and $02(02 \%)$ were Candida sp. (Table 04)

\begin{tabular}{|c|c|c|c|}
\hline $\begin{array}{c}\text { Total Isolates } \\
\text { (N) }\end{array}$ & $\begin{array}{c}\text { Gram-Positive } \\
\text { Bacteria } \\
\text { n (\%) }\end{array}$ & $\begin{array}{c}\text { Gram-Negative } \\
\text { Bacteria } \\
\text { n (\%) }\end{array}$ & $\begin{array}{c}\text { Candida sp. } \\
\text { n (\%) }\end{array}$ \\
\hline 100 & $62(62 \%)$ & $36(36 \%)$ & $02(02 \%)$ \\
\hline
\end{tabular}

Table 4. Distribution of All the Organisms in Blood Culture

BACTEC 9050 detected all positive samples within 24 hours while conventional method detected none within 24 hrs, $25.4 \%$ within 48 hours \& $84.7 \%$ within 96 hours.

The mean time to detection by the BACTEC 9050 was 11.3, 11.0 and 23 hours for gram-positive bacteria, gramnegative bacteria and fungi respectively. Total time taken for 
detection of bacterial isolates by conventional methods was up to 2-7 days with repeated subcultures.

The highest rate of recovery of isolates was by BACTEC 9050 i.e. $95 \%(95 / 100)$ as compared to conventional blood culture methods $60 \%(60 / 100)$. There were 34 samples (35.7\%) which were found to be positive only by BACTEC 9050. (Table 05)

\begin{tabular}{|c|c|c|c|c|c|c|c|}
\hline \multirow[t]{2}{*}{$\begin{array}{c}\text { Type of } \\
\text { Organisms }\end{array}$} & \multirow[t]{2}{*}{\begin{tabular}{|c} 
Total No. \\
of \\
Isolates \\
$(100)$
\end{tabular}} & \multicolumn{2}{|c|}{$\begin{array}{c}\text { Detection } \\
\text { Time of } \\
\text { BACTEC } \\
\text { (Hours) }\end{array}$} & \multirow[t]{2}{*}{$\begin{array}{l}\text { Mean } \\
\text { Time } \\
\text { (hrs.) }\end{array}$} & \multicolumn{2}{|c|}{\begin{tabular}{|c|} 
Detection \\
time of \\
Conventional \\
Method \\
(Hours)
\end{tabular}} & \multirow[t]{2}{*}{$\begin{array}{l}\text { Mean } \\
\text { Time } \\
\text { (hrs.) }\end{array}$} \\
\hline & & Max. & Min. & & Max. & Min. & \\
\hline \multicolumn{8}{|c|}{ Gram-Positive Bacteria } \\
\hline $\begin{array}{c}\text { Methicillin } \\
\text { Resistant CONS } \\
\text { (MRCONS) }\end{array}$ & 34 & 18 & 06 & 12 & 120 & 48 & 84 \\
\hline Enterococcus sp. & 09 & 14 & 08 & 11 & 96 & 48 & 72 \\
\hline $\begin{array}{c}\text { Coagulase- } \\
\text { negative } \\
\text { Staphylococcus } \\
\text { (CONS) }\end{array}$ & 07 & 18 & 11 & 14.5 & 144 & 48 & 96 \\
\hline $\begin{array}{l}\text { Staphylococcus } \\
\text { aureus (MSSA) }\end{array}$ & 03 & 15 & 12 & 13.5 & -- & -- & -- \\
\hline $\begin{array}{c}\text { Methicillin } \\
\text { Resistant } \\
\text { Staphylococcus } \\
\text { aureus (MRSA) }\end{array}$ & 02 & 10 & 07 & 08.5 & 48 & 48 & 48 \\
\hline Micrococcus & 01 & 09 & 09 & 09 & 48 & 48 & 48 \\
\hline $\begin{array}{l}\text { Streptococcus } \\
\text { pneumoniae }\end{array}$ & 01 & 11 & 11 & 11 & -- & -- & -- \\
\hline Diphtheroids & 02 & -- & -- & -- & 36 & 48 & 42 \\
\hline $\begin{array}{c}\text { Aerobic Spore } \\
\text { Bearer }\end{array}$ & 03 & -- & -- & -- & 48 & 48 & 48 \\
\hline Total & 62 & & & $\begin{array}{c}11.3 \\
(79.5 / 7) \\
\end{array}$ & & & $\begin{array}{c}62.6 \\
(438 / 7)\end{array}$ \\
\hline \multicolumn{8}{|c|}{ Gram-Negative Bacteria } \\
\hline Pseudomonas sp. & 14 & 12 & 06 & 09 & 120 & 48 & 84 \\
\hline $\begin{array}{c}\text { Acinetobacter } \\
\text { baumannii }\end{array}$ & 09 & 16 & 08 & 12 & 120 & 48 & 84 \\
\hline Salmonella Typhi & 05 & 16 & 06 & 11 & 96 & 48 & 72 \\
\hline E. coli & 05 & 16 & 8 & 12 & 36 & 24 & 15 \\
\hline Enterobacter sp. & 01 & 11 & 11 & 11 & 48 & 48 & 48 \\
\hline $\begin{array}{c}\text { Acinetobacter } \\
\text { lwoffii }\end{array}$ & 01 & -- & -- & -- & -- & -- & -- \\
\hline Klebsiella sp. & 01 & 11 & 11 & 11 & -- & -- & -- \\
\hline Total & 36 & & & $11(66 / 6)$ & & & $\begin{array}{c}60.6 \\
(303 / 5)\end{array}$ \\
\hline \multicolumn{8}{|c|}{ Fungi } \\
\hline Candida sp. & 02 & 24 & 22 & 23 & -- & -- & -- \\
\hline All Organisms & 100 & & & $\begin{array}{c}12.0 \\
(168.5 / 14) \\
\end{array}$ & & & $\begin{array}{c}61.7 \\
(741 / 12) \\
\end{array}$ \\
\hline $\begin{array}{r}\text { Table 5. Distr } \\
\text { Isolates by BAC }\end{array}$ & $\begin{array}{l}\text { ibution a } \\
\text { TEC } 9050\end{array}$ & - & Con & $\begin{array}{l}\text { ime of Det } \\
\text { entional B }\end{array}$ & $\begin{array}{l}\text { tectic } \\
\text { Blood }\end{array}$ & $\begin{array}{l}\text { of } B c \\
\text { altur }\end{array}$ & $\begin{array}{l}\text { terial } \\
\text { Method }\end{array}$ \\
\hline
\end{tabular}

Maximum pathogenic isolates detected among grampositive bacteria by both conventional blood culture and BACTEC 9050 were Methicillin Resistant Coagulase-negative Staphylococcus (MRCONS) and Enterococcus. However, the members of the Enterobacteriaceae family were the most frequently isolated strains among the gram-negative bacteria.

\begin{tabular}{|c|c|c|c|}
\hline \multirow{2}{*}{ BACTEC 9050 } & \multicolumn{2}{|c|}{$\begin{array}{c}\text { Conventional Blood Culture } \\
\text { Method }\end{array}$} & Total Cases \\
\cline { 2 - 4 } & Positive Cases & Negative Cases & \\
\hline Positive & $56(\mathrm{TP})$ & $34(\mathrm{FP})$ & 90 \\
\hline Negative & $03(\mathrm{FN})$ & $161(\mathrm{TN})$ & 164 \\
\hline Total & 59 & 195 & 254 \\
\hline
\end{tabular}

Table 6. Efficacy of BACTEC 9050 with Respect to Conventional Blood Culture Method

TP = True Positive; FN = False Negative; FP = False Positive; TN= True Negative

The Sensitivity, Specificity, Positive Predictive value and Negative predictive value of BACTEC 9050 was found to be $94.9 \%, 82.5 \%, 62.2 \%$ and $98.1 \%$ respectively as compared to conventional culture method. (Table $06 \& 07$ )

\begin{tabular}{|c|c|c|}
\hline Sensitivity & $\begin{array}{c}{[\mathrm{TP} /(\mathrm{TP}+\mathrm{FN})]^{*} 100} \\
{[56 /(56+03)]^{*} 100}\end{array}$ & $94.9 \%$ \\
\hline Specificity & $\begin{array}{c}{[\mathrm{TN} /(\mathrm{TN}+\mathrm{FP})]^{*} 100} \\
{[161 /(161+34)]^{*} 100}\end{array}$ & $82.5 \%$ \\
\hline $\begin{array}{c}\text { Positive Predictive } \\
\text { Value }\end{array}$ & $\begin{array}{c}{[\mathrm{TP} /(\mathrm{TP}+\mathrm{FP})]^{*} 100} \\
{[56 /(56+34)]^{*} 100}\end{array}$ & $62.2 \%$ \\
\hline $\begin{array}{c}\text { Negative Predictive } \\
\text { Value }\end{array}$ & $\begin{array}{c}{[\mathrm{TN} /(\mathrm{TN}+\mathrm{FN})]^{*} 100} \\
{[161 /(161+03)]^{*} 100}\end{array}$ & $98.1 \%$ \\
\hline $\begin{array}{c}\text { Table 7. Sensitivity, Specificity, Positive Predictive Value and } \\
\text { Negative Predictive Value of BACTEC and The Conventional } \\
\text { Method }\end{array}$ \\
\hline \multicolumn{3}{|c}{} \\
\hline
\end{tabular}

\section{DISCUSSION}

Bloodstream infection is one of the most serious problems in all infectious diseases. Blood culture is one of the most important tools in the clinical microbiology laboratory. Rapid isolation and identification of the microorganisms in blood samples has both therapeutic and prognostic significance and critically important in order to reduce the mortality rate.[14] In present study, males constituted majority (53.7\%) of the patients with male to female ratio of 1.16:1 from rural background (56\%). This finding was similar with Avneet Kaur et al. 2014[7] who reported male predominance (65.22\%) with rural background (65.22\%). Gopi et al. (2011) ${ }^{17}$ also reported male predominance with male female ratio as 1.44:1. The increase member of male patients over female might be due to occupational exposure.

In our study, Maximum patients were found in the younger age group of less than 20 years (60.21\%). These results are consistent with the study done by Avneet Kaur et al. $2014{ }^{[7]}$ who reported $52.17 \%$ patients below 20 years.

In the present study, blood culture positivity was seen in $36.6 \%$ cases with $95 \%$ pathogenic isolates comprising of $57 \%$ gram-positive and 36\% gram-negative bacteria, and $2 \%$ Candida isolates. These results are similar with the study done by Jung et al (1999)[15] and Handa et al who reported $43.8 \%$ infectious causes of fever of unknown origin (FUO).[16] Gopi et al (2011)[17] in their study also reported the similar isolation rate among clinically significant pathogens [i.e. gram-positive bacteria (61.52\%), gram-negative bacteria $(36.94 \%)$ and yeast $(1.52 \%)]$. However contrary to present study, Durmaz et al (2003) ${ }^{[8]}$ reported more gram-negative isolates from FUO cases.

In present study, maximum isolates of gram-positive bacteria were Methicillin Resistant Coagulase-negative Staphylococcus (MRCONS) (59.6\%) followed by Enterococcus sp. (15.7\%), Coagulase-negative Staphylococcus 
(CONS)(12.2\%), Staphylococcus aureus (5.2\%), Methicillin Resistant Staphylococcus aureus (MRSA) (3.5\%), Micrococcus \& Streptococcus pneumoniae (1.7\% each). These findings are in agreement with study done by Avneet Kaur et al. 2014[7] \& Gopi et al (2011)17 who reported Coagulase-negative Staphylococcus as predominant gram-positive bacterial isolates. In our study, although the most predominant gramnegative bacteria detected was Pseudomonas sp. (38.8\%), but the members of the Enterobacteriaceae family were the most frequently isolated strains among the gram-negative bacteria. This finding was in concordant with the study by Avneet Kaur et al 2014, [7] Durmaz et al. (2003),,8] Bayram et al.[14] and Gopi et al. (2011). ${ }^{17}$

This study evaluates the capability, efficiency and reliability of BACTEC 9050 in comparison to conventional blood culture for detection of bacterial isolates. One of the main advantages of the BACTEC system found from the results of our study was that this system yielded more significant isolates in a shorter time as compared to the conventional system.

The highest rate of recovery of pathogenic isolates was by BACTEC 9050 i.e. $95 \%$ as compared to conventional blood culture methods (60\%). There were 34 samples (35.7\%) which were found to be positive only by BACTEC 9050 and not by Conventional blood culture methods.

The mean detection time taken by BACTEC 9050 for gram-positive bacteria, gram-negative bacteria and Candida $s p$. in this study were 11.3 hours, 11 hours and 23 hours respectively. Overall mean time for all the pathogens is 12 hours. Conventional methods took up to 2-7 days to detect positive bacterial isolates with repeated subcultures. These results are consistent with the study done by Durmaz et al. (2003) ${ }^{[8]}$ who reported mean detection times for the grampositive bacteria, the gram-negative bacteria, and the yeasts as $18.83,15.67$ and 23.87 hours, respectively. Avneet Kaur et al 2014[7] reported mean detection time for gram-positive bacteria and gram-negative bacteria to be 19.33 hours and 19.06 hours respectively. Gopi et al (2011)[17] also reported the mean detection time for the clinically significant isolates by BACTEC 9050 as 21 hours with 9\% pathogenic positive cultures.

Hence, BACTEC 9050 system has proved to be a reliable, efficient and more sensitive instrument for detecting pathogenic isolates as compared to conventional blood culture methods.

\section{CONCLUSIONS}

In our study, $100 \%$ positive samples were detected by BACTEC 9050 in first twenty-four hours. Rate of detection of bacterial isolates by the BACTEC 9050 was also significant $(95 \%)$ as compared to conventional method (60\%). Furthermore, mean time to detection of significant pathogens was significantly less with the BACTEC 9050 (11.3, 11.0 and 23 hours for gram- positive bacteria, gram-negative bacteria and fungi respectively). The sensitivity, specificity, PPV and NPV found to be high with BACTEC 9050. Therefore, automated blood culture systems are a reliable and rapid technique in identification of the blood stream pathogens in comparison to conventional culture methods.

\section{REFERENCES}

[1] Young LS, Sepsis syndrome. In: Mandell GL, Bennet JE, Dolin R, eds. Principle and practice of infectious diseases. $4^{\text {th }}$ edn. New York: Churchill Livingstone 1995: p. 690-705.

[2] Fuselier PA, Garcia LS, Procop GW, et al. Blood stream infections. In: Betty AF, Daniel FS, Alice SW, eds. Bailey and Scot's Diagnostic Microbiology. Mosby 2002: p. 865-83.

[3] Trevini S, Mahon CR. Bacteraemia. In: Connie RM, Manusel G, eds. Textbook of Diagnostic microbiology. W B Saunders 2000: p. 998-1008.

[4] Elhag KM, Mustafa AK, Sethi SK. Septicaemia in a teaching hospital in Kuwait-I: incidence and aetiology. Journal of Infection 1985;10(1):17-24.

[5] Crowe M, Ispahani P, Humphreys $\mathrm{H}$, et al. Bacteraemia in the adult intensive care unit of a teaching hospital in Nottingham, UK, 1985-1996. European Journal of Clinical Microbiology and Infectious Diseases 1998;17(6):377-84.

[6] Garg A, Anupurba S, Garg J, et al. Bacteriological profile and antimicrobial resistance of blood culture isolates from a university hospital. Journal of Indian Academy of Clinical Medicine 2007;8(2):139-43.

[7] Kaur A, Soodan PS, Singh VA. Comparative evaluation of conventional blood culture with bactec 9050 for bacterial isolates in clinically suspected cases of fever of unknown origin. IOSR Journal of Dental and Medical Sciences (IOSR-JDMS) 2014;13(7):17-21.

[8] Durmaz G, Us T, Aydinli A, et al. Optimum detection times for bacteria and yeast species with the BACTEC 9120 aerobic blood culture system: Evaluation for a 5year period in a Turkish University Hospital. J Clin Microbiol 2003;41(2):819-21.

[9] Dokuzoguza B, Ergonul O, Baykam N, et al. Characteristics of B. melitensis versus B. abortus bacteraemias. J Infect 2005;50(1):41-5.

[10] BACTEC 9050 System User's Manual. Document Number MA-0103. BD Biosciences.

[11] BACTEC $^{\text {тм }}$ PLUS Aerobic/F and PLUS Anaerobic/F Culture Vials Insert Rev. PP-088E BD Biosciences.

[12] BACTEC ${ }^{\mathrm{TM}}$ PEDS PLUS/F Culture Vials Insert. Rev. PP091-I. BD Biosciences.

[13] Collee JG, Marr W. Culture of Bacteria. Mackie and McCartney Practical Medical Microbiology. 14th edn. Elsevier 2008: p. 123-4.

[14] Bayram A, Alkan GN, Balci I. Microorganisms isolated from a continuous monitoring blood culture system: BACTEC 9240. J Turk Microbiol Soc 1997;27:64-7.

[15] Jung A, Singh MM, Jajoo U. Unexplained fever- analysis of 233 cases in a referral hospital. Indian J Med Sci 1999;53(12):535-44.

[16] Handa R, Singh S, Singh N, et al. Brucellosis in north India: results of a prospective study. J Commun Dis 1998;30(2):85-7.

[17] Gopi A, Ravikumar KL, Ambarish MG, et al. Time to positivity of microorganisms with BACTEC 9050. An 18-month study among children of 28 days to 60 months in a South Indian Tertiary Hospital. International Journal of Microbiological Research 2011;2(1):12-7. 